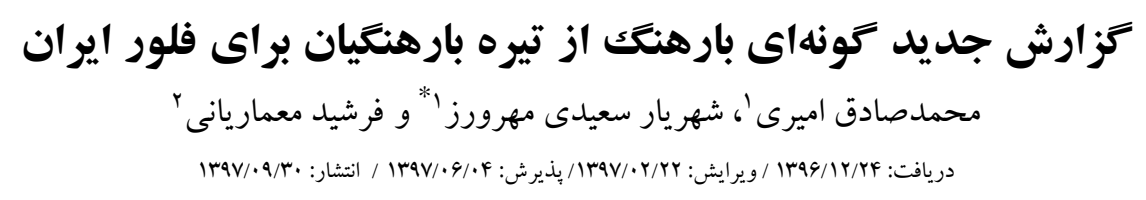

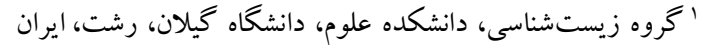

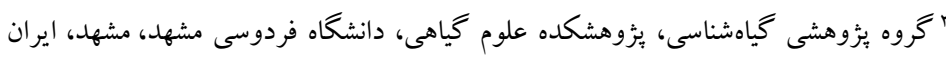

$$
\begin{aligned}
& \text { مسئول مكاتبات: Saeidimz@ guilan.ac.ir }
\end{aligned}
$$

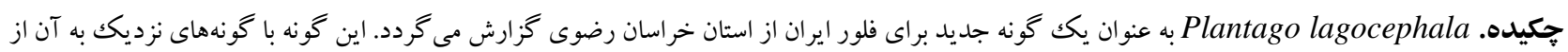

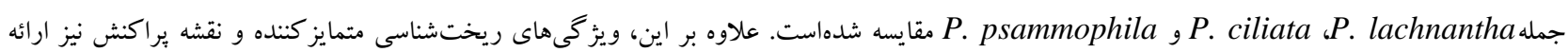

$$
\text { وازههاى كليدى. خراست. وضعيت حفاظتى ززارش جديد براساس ردهبندى و معيارهاى IUCN ارزيابى شده است. }
$$

\title{
Plantago lagocephala (Plantaginaceae), a new record for the flora of Iran
}

\author{
Mohammad Sadegh Amiri ${ }^{1}$, Shahryar Saeidi Mehrvarz ${ }^{1 *}$, Farshid Memariani ${ }^{2}$ \\ Received: 15.03.2018 / Revised:12.05.2018 / Accepted: 26.08.2018 / Published:21.12.2018

\footnotetext{
${ }^{1}$ Department of Biology, Faculty of Science, University of Guilan, Rasht, Iran

${ }^{2}$ Department of Botany, Research Center for Plant Sciences, Ferdowsi University of Mashhad, Mashhad, Iran

*Correspondent author: saeidimz@guilan.ac.ir
}

\begin{abstract}
Plantago lagocephala is recorded as a new species for the flora of Iran from Razavi Khorassan Province. It is compared with the closely related species including P. lachnantha, P. ciliata and P. psammophila. Moreover, the diagnostic morphological characters and a distribution map are provided. The conservation status of the new record is evaluated based on the IUCN red list categories and criteria.
\end{abstract}

Keywords. conservation status, distribution map, Khorassan, morphology, related species

\section{INTRODUCTION}

Plantago L. (Plantaginaceae) comprises nearly 250 species in the world and its main centers of diversity are located in the temperate zone and also in high-elevations of the tropical regions, ranging from cosmopolitan weeds to extremely narrow endemics (Pilger, 1937; Rahn, 1996; Hassemer, 2016). The morphology and taxonomy of this genus are complex, and still present uncertainties regarding its phylogenetic relationships and species delimitations (Hassemer, 2016). It encompasses 28 species in the Flora Iranica area and 24 species in Iran, of which 5 species are endemics (Patzak \&
Rechinger, 1965; Mozaffarian, 2007; Mohsenzadeh et al., 2007, 2010; Hassemer, 2018). Although botanists have visited most parts of Iran, some areas are unexplored yet. During the field investigations in the mountains of Zarrin Kuh Protected Area (ZPA), Razavi Khorassan Province (NE Iran) we found some peculiar populations of a Plantago species. A closer study of living material and herbarium specimens suggested that the specimens were similar to $P$. lachnantha Bunge, $P$. ciliata Desf. and P. psammophila Agnew \& Chal.-Kabi. 


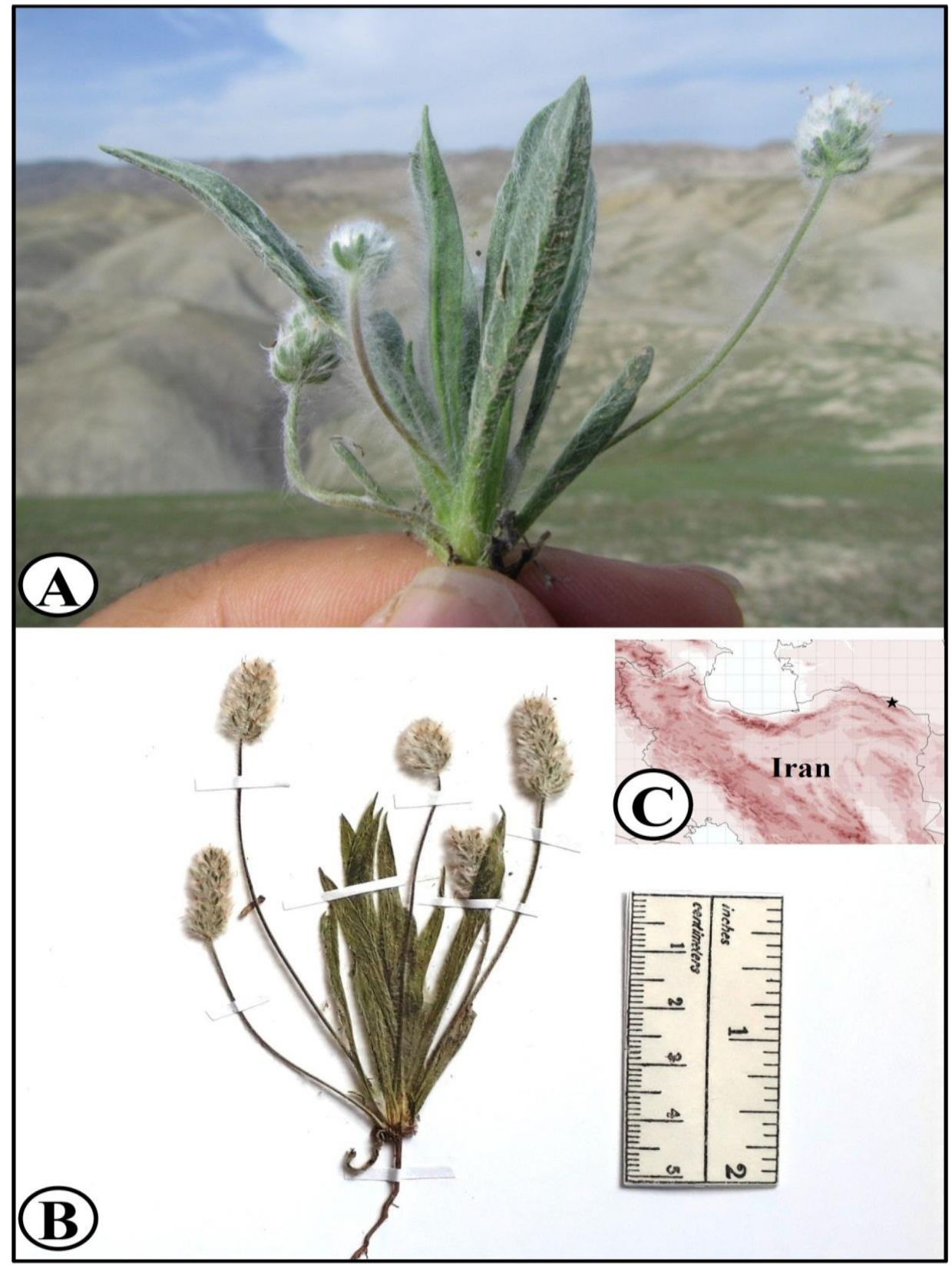

Fig. 1. Plantago lagocephala: A: in natural habitat, Zarrin Kuh Protected Area; Photograph taken by M.S. Amiri. B: herbarium specimen (Joharchi \& Memariani 45716-FUMH); C: distribution map of the new record in NE Iran.

However, there were also several morphological differences. After examining the specimens carefully, they were identified to be a new record for the genus, namely Plantago lagocephala Bunge for the flora of Iran. Morphological features (i.e. leaf shape and the length of spike peduncle, bracts and corolla lobes) in this taxon are good characters for the separation of these closely related species (Table 1). In this paper, the diagnostic characters of this taxon, its distribution map and its conservation status, based on the IUCN Red list categories, are discussed.

\section{MATERIALS AND METHODS}

The herbarium specimens were collected from Zarrin Kuh Protected Area in Razavi Khorassan Province, NE Iran during 2015-2017 in flowering and fruiting periods. The vegetative and reproductive characteristics of the specimens were studied by means of a stereomicroscope. Descriptions of the new record and its close relatives were compared using the relevant Flora, especially the Flora Iranica (Patzak \& Rechinger, 1965). The plant specimens are deposited in the herbarium of the Ferdowsi University of Mashhad (FUMH). The International Plant Names Index (http://ipni.org) was consulted for the standard scientific and author names of the plant species. 
Table 1. Comparison of diagnostic morphological characters of Plantago lagocephala with its closely related species.

\begin{tabular}{|c|c|c|c|c|}
\hline $\begin{array}{c}\text { Taxon } \rightarrow \text { Character } \downarrow \\
\text { lachnantha }\end{array}$ & Plantago lagocephala & Plantago ciliata & $\begin{array}{c}\text { Plantago } \\
\text { psammophila }\end{array}$ \\
\hline $\begin{array}{c}\text { Leaves shape and } \\
\text { size } \\
(\mathrm{cm})\end{array}$ & $\begin{array}{c}\text { narrowly linear, } \\
3-5 \mathrm{~cm}\end{array}$ & $\begin{array}{c}\text { narrowly lanceolate, } \\
2-5 \mathrm{~cm}\end{array}$ & $\begin{array}{c}\text { obovate or } \\
\text { lenceolate- } \\
\text { spathulate, } 3-4 \mathrm{~cm}\end{array}$ & $\begin{array}{c}\text { linear-lanceolate or } \\
\text { oblong, } 3-6 \mathrm{~cm}\end{array}$ \\
\hline $\begin{array}{c}\text { Spike peduncle } \\
\text { length } \\
(\mathrm{cm})\end{array}$ & $1.5-2 \mathrm{~cm}$ & $4-8 \mathrm{~cm}$ & $1-7 \mathrm{~cm}$ & $3-8 \mathrm{~cm}$ \\
\hline $\begin{array}{c}\text { Bracts length } \\
(\mathrm{mm})\end{array}$ & $4.5-5 \mathrm{~mm}$ & $3 \mathrm{~mm}$ & $3.5 \mathrm{~mm}$ & $4 \mathrm{~mm}$ \\
\hline $\begin{array}{c}\text { Corolla lobes length } \\
(\mathrm{mm})\end{array}$ & $1.5-1.75 \mathrm{~mm}$ & up to $1 \mathrm{~mm}$ & $1.5 \mathrm{~mm}$ & \\
\hline
\end{tabular}

\section{RESULTS AND DISCUSSION}

Plantago lagocephala Bunge, Mém. Acad. Imp. Sci. St.-Pétersbourg Divers Savans 7: 445 (1851). (Fig. 1).

Annual herbs, small to $8-10 \mathrm{~cm}$ tall. Leaves rosettes, erect, papery, $2-5 \mathrm{~cm}$ long, $2-5 \mathrm{~mm}$ broad, narrow-lanceolate, obtuse. Spike peduncle $4-8 \mathrm{~cm}$ long, arcuate-ascendent, villose. Spikes dense, ovoid, $8 \mathrm{~mm}$ long in flower, later in fruits cylindrical, up to $20 \mathrm{~mm}$ long. The bracts broadly ovate, ciliate, up to $3 \mathrm{~mm}$ long, keeled. Sepals lanceolate-ovate, $3 \mathrm{~mm}$ long, keeled. Corolla tube glabrous; corolla lobes ovate, hairy, up to $1 \mathrm{~mm}$ long. Capsule ellipsoid; seeds 2, yellowish-brown, elliptic to narrow ovate-elliptic.

Specimen seen: Iran: Razavi Khorassan province, NW Dargaz, ca. $5 \mathrm{~km}$ NE Nokhandan, northern foothills of Zarrin Kuh Protected Area, 490-550 m, 26 April 2016, Joharchi \& Memariani 45716 (FUMH).

General distribution: An Aralo-Caspian species distributed mainly in Kara-Kum, Kyzyl-Kum, and Amu-Darya (Turkmenistan, Kazakhstan, Uzbekistan, Tajikistan) (Shishkin, 1958), and also in N-NE Afghanistan (Baghlan and Bamian) (Podlech, 2012), Pakistan (Balochistan) (Patzak \& Rechinger, 1965), China (N Xinjiang) (eFloras, 2018), and NE Iran (the present work).

\section{Habitat and ecology}

Plantago lagocephala occurs in elevations ranging from 490 to $550 \mathrm{~m}$, on the foothills of Zarrin Kuh. Biogeographically, the area belongs to the central part of Khorassan-Kopet Dagh floristic province. It grows on clay-gypsum and marl hills. The vegetation in such habitats is very sparse and usually species-poor. The carbonate-rich soil and gypsum, very dry substrate, and lack of organic material represent stressful conditions for many plant species. Therefore, highly specialized xerophilous species, known as gypsophilous or calciphilous species, grow on such soils (Memariani et al., 2016). The following taxa exist abundantly in its locality: Galium tricornutum Dandy, Zygophyllum atriplicoides Fisch. \& C. A. Mey., Cephalorhizum turcomanicum Popov, Heterocaryum szovitsianum (Fisch. \& C.A.Mey.) A.DC., Valerianella dufresnia Bunge ex Boiss., Holosteum umbellatum L. subsp. glutinosum (M. Bieb.) Nyman, Gypsophila heteropoda Freyn \& Sint. and Alyssum desertorum Stapf.

\section{Conservation status}

This species was very rare in the area and was found only in a few localities, where its habitat had recently been greatly affected by road construction and intensive grazing. Concerning the small extent of occurrence and the low number of $P$. lagocephala in this area, the recommended IUCN Red category of this species is evaluated as regionally Critically Endangered (CR).

\section{ACKNOWLEDGEMENT}

This paper is a part of the results of the Ph.D. thesis of the first author supported by the University of Guilan. The authors are thankful for the financial support of this University. We are also indebted to M.R. Joharchi (FUMH) for his valuable advice and constructive comments during the identification of the species. 


\section{REFERENCES}

Hassemer, G. 2016. Plantago hatschbachiana (Plantaginaceae), a critically-endangered new species from sandstone grasslands in Brazil, and an updated identification key to Plantago in Brazil and Paraguay. - Phytotaxa 278: 141-52.

Hassemer, G. 2018. Notes on the montane IndoIranian species in Plantago subgenus Plantago (Plantaginaceae). - Phytotaxa 336: 59-68.

IUCN .2016. Guidelines for Using the IUCN Red List Categories and Criteria. Version 12. Prepared by the Standards and Petitions Subcommittee. Available from: http://www.iucnredlist.org/ documents/RedListGuidelines.pdf (accessed 8 March 2017)

Memariani, F., Zarrinpour, V. and Akhani, H. 2016. A review of plant diversity, vegetation, and phytogeography of the Khorassan-Kopet Dagh floristic province in the Irano-Turanian region (northeastern Iran-southern Turkmenistan). Phytotaxa 249: 8-30.

Mohsenzadeh, S., Nazeri, V. and Mirtadzadini, A.S. 2007. Plantago lachnantha Bge. (Plantaginaceae), a new record for flora of Iran. - Iran. J. Bot. 13: 107-108.

Mohsenzadeh, S., Nazeri, V. and Mirtadzadini, M. 2010. A new species of Plantago (Plantaginaceae) from Iran. - Novon 20: 307-310.

Mozaffarian, V. 2007. A Dictionary of Iranian Plant Names. Farhang-e-Moaser, Tehran. pp: 417-418.

Patzak, A. and Rechinger, K. H. 1965. Plantaginaceae. - In: Rechinger, KH (ed.). Flora Iranica 15: 1-21. - Academische Druck und Verlagsantalt.

Pilger, R.K.F. 1937. Plantaginaceae. - In: Engler, H.G.A. \& Diels, F.L.E. (eds.). Das Pflanzenreich. 102: 466 pp. Wilhelm Engelmann, Leipzig.

Rahn, K. 1996. A phylogenetic study of the Plantaginaceae. - Bot. J. Linn. Soc. 120: 145-198.

$$
* * * * *
$$

How to cite this article:

Amiri, M.S., Saeidi Mehrvarz, Sh. and Memariani, F. 2018. Plantago lagocephala (Plantaginaceae), a new record for the flora of Iran. - Nova Biol. Reperta 5 (3): 320-323. 